\title{
Adaptation and embedding of modern military objects on the example of the Kłodzko Fortress
}

\author{
Katarzyna Drobek \\ https://orcid.org/0000-0003-3599-1169 \\ k.drobek@pollub.pl \\ Department of Conservation of Built Heritage, Faculty of Civil Engineering \\ and Architecture, Lublin University of Technology
}

\begin{abstract}
The issue of adaptation and modernization of fortifications is very important nowadays. Military objects have lost their original purpose and have largely been left alone. Recently there has been a constant increase in interest in the military. This causes that more and more such objects are being adapted to the new function. This is the only way to protect them from degradation. An excellent example of this type of objects is the Kłodzko Fortress, which belongs to the best preserved and most impressive Silesian fortifications and is a unique example of military architecture on a Polish scale. After it was abandoned by the military, the technical condition of the object significantly deteriorated. The reason for that were attempts to introduce new functions to it. Currently, works are being carried out in order to remove some of the secondary layers. However, in order for the object to function properly nowadays it is necessary to create a plan for its modernization, which would cover the whole Fortress. Gradual changes would ensure efficient functioning and its development in the future.
\end{abstract}

Keywords: fortress, fortifications, military object, the Kłodzko Fortress, adaptation

\section{Introduction}

The growing interest in the history of the art of war and the military, is the reason for the development of various forms of cultural tourism around the world. Poland, as a result of its exceptionally turbulent history, has a huge stock of military objects originating mainly from the period of the Republic of Poland and the partitions. All Polish fortifications from the pre-partition period and from the period of the Duchy of Warsaw: Prussian, Austrian and Russian fortifications come from one European trunk. They have their specificity and they are monuments of the European military art. ${ }^{1}$

The fortifications, due to constant modernization, connected with the evolution of war technology, have irretrievably lost their military importance and thus became a cultural monument. Knowledge of military objects and fortifications until the 1970s was very limited, as information was largely classified by the military. The first works on the objects took place in the interwar period. Relatively recently, research work on a larger scale has begun.

After 1989, as a result of system changes, these objects were demilitarized and the military began to leave the fortifications. This resulted in a sudden transformation of ownership of the post-war areas, which in turn made it necessary to issue conservation decisions relating to further actions and use of these objects. ${ }^{2}$ The greatest devastation of the historic matter took place after the army left the fortifications, as the later chaotic attempts to introduce new functions caused the technical condition of the facility to gradually degrade. 


\section{The Kłodzko Fortress}

The Kłodzko Fortress, which is the subject of this study, belongs to the continuation of the Sudetenland fortification belt. Together with the auxiliary fort, the Owcza Góra, next to the Fortress in Srebrna Góra, is the most impressive and best preserved of the Silesian fortifications. ${ }^{3}$ It is also a remarkable example of the military architecture. It was built on a rocky peak called the Forteczna Mountain. It was created as a result of reconstruction of a medieval castle. Thanks to such a location, it has been equipped with a variety of original solutions, including mineral corridors, which reflect the development of defensive art related to the period of artillery domination.

Currently, the Kłodzko Fortress is one of its greatest attractions. It consists of about 30 defensive works, created as a result of many historical transformations. The fortification and spatial structure of the town, apart from the Fortress itself, also includes the Owcza Góra Fort, which closes the Nysa River valley from the east. The fortifications of Kłodzko also include numerous town fortifications erected around the town, outlining the original settlement, and a fortified camp, which complemented the town defense system from the southern side.

This object is undoubtedly the largest and most dominant point of the city landscape. It also has an extremely complex military layout. From the side of the city, the multithreaded character of the Fortress can be seen, and the multi-level defensive ramparts, stacked on the slope of the mountain, show the huge scale of the Fortress. The crowning point of the Kłodzko Fortress is the Donjon, a building with a ticked shape, which is the redoubt, the last point of defense.

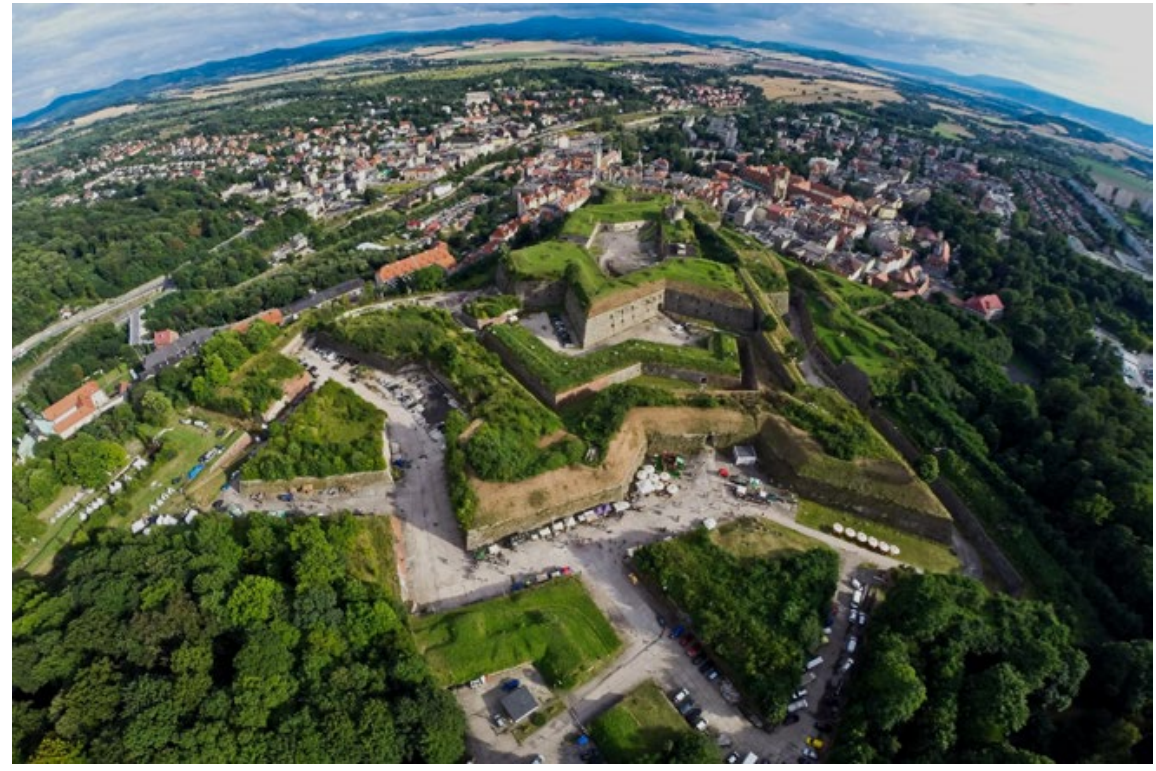

Fig. 1. The Kłodzko Fortress from the bird's eye view, source: https://www.polskieszlaki.pl/twierdza-klodzka. htm, author: Kamil Glaz

The entire urban complex of the Kłodzko Fortress has been preserved almost entirely until the 1940s. The greatest damage was done in the post-war period. It is the result of the destructive activity of various institutions using the building. Some of the damage was also caused by negligence related to the maintenance of vegetation. The damage mainly concerned filling in the moats, demolishing parts of the object and the aforementioned greenery damage. 


\section{Historical background}

The original development of the Kłodzko hill, on the western side of the Nysa Klodzka River, was a medieval castle, existing in the $14^{\text {th }}$ century, and then rebuilt in the $16^{\text {th }}$ century. ${ }^{4}$ Works on the fortifications of the Kłodzko castle began already during the stationing of the Czech king Frederick V together with the army in $1620 .{ }^{5}$ The siege of the town in 1622 combined with an artillery bombardment forced the Austrians to start renovation and modernization work on the castle. ${ }^{6}$ Kłodzko gained a modern fortress in the shape of a typical citadel.

The breakthrough for the history of the Kłodzko castle was the year 1742, when Frederick II conquered the fortress - the Kłodzko citizens were forced to surrender the town due to the insufficient level of fortifications. This resulted in the appearance of General Gerard Kornelius Walrave (1692-1773) as the main designer of the reconstruction of the Kłodzko Fortress. ${ }^{7}$

After the Austrians took over the Fortress in 1760, many modernization works began, including the creation of Donjon. The castle, located at the top of the mountain, was completely demolished, and in its place there was a huge three-storey defensive redoubt with an observation tower.

The Fortress, over the years of its operation, has repeatedly changed its purpose. In 1944 the AEG armaments factory operated on its premises. Among other things, parts for the V-1 bullets were manufactured. ${ }^{8}$ After the war, the building was taken over by the local army, which was stationed here until 1957. In later years, attempts were made to adapt the fortress for various types of economic activities, such as fish and egg headquarters, mushrooms, reinforced concrete plants, or the Rosvin Wine Cellars known in the region. ${ }^{9}$

\section{The Kłodzko Fortress - analysis of historical values}

The Kłodzko Fortress is one of the most valuable and longest functioning defense teams in Poland. The first mention of the existing castle dates back to the second half of the $10^{\text {th }}$ century. Rebuilt in the Middle Ages and the Renaissance, it received its final form in the eighteenth century. The fortress has a nearly 1,000-year-old shell of layers created in connection with key events in Polish and European history. "This historic defensive ensemble (...) is a creation of European martial art created from centuries-old layers of different fortification systems and schools: Italian, Dutch, Austrian, French and Prussian, and the creative concepts of famous fortificators. ${ }^{10}$ It is a document of the past, and therefore has great scientific value and significant historical value that should be protected.

The destructive economic activity conducted after the 1950s significantly devastated individual areas of the Fortress. A part of the curtains was demolished, the historic shape was destroyed, the moats were concreted and buried, and new buildings, halls and warehouses were built in the moat before the Crown work. The Poterna, which connected the square between the Donjon and Wielki Kleszcz with Lukasinskiego St., was also destroyed. A chimney and a technical building were built on it, and a road in a not very aesthetic form was laid nearby. All works related to the adaptation of this facility to the previous activities were performed in a chaotic way, without respect for the historical fabric.

The basic and most important monumental value is the form of the object, which directly results from the function that the Kłodzko Fortress used to have. As far as the function is concerned, one should focus on its logic. Military objects are an exceptional case, where the function determines all elements of the building, and its diversity is a significant element in the context of numerous transformations. Accumulated historical and

4 Information on the architectural outline of the Kłodzko castle based on: B. Guerquin, Zamki Śląskie, Warszawa 1957; Broniewski T., Kłodzko [w:] Śląsk w zabytkach sztuki, Wrocław 1963

5 Dziewulski W., Zarys rozwoju przestrzennego Kłodzka od czasów najdawniejszych do drugiej wojny światowej, T.III, Kłodzko 1959, s. 36.

6 Triller E., O Lisowczykach w Ziemi Kłodzkiej, [w:] Rocznik Ziemi Kłodzkiej 1958, T.III, Kłodzko 1959, s. 139.

Bukal G., Gerhard Cornelius Walrave i holendersko-pruska fortyfikacja na ziemiach polskich, Warszawa 1995 r.

www.dawnekłodzko.pl, access date: 15.01.2018 r.

www.zamkipolskie.pl, access date: 24.01.2018 r.

10 Małachowicz M., Karnicki R., Podruczny G., Plan ochrony parku kulturowego dla Fortecznego Parku Kulturowego - Twierdza Kłodzko w Kłodzku, Wrocław - Kłodzko V 2007 r., s. 5. 
architectural layers make it so unique. Multi-level defensive ramparts, spread out in steps along the slope of the mountain, are a characteristic feature of this type of architecture.

The Main Fortress also has a number of utility values. There are many places with different adaptations. The aforementioned economic activity on the military facility and the use of it for storage purposes did not improve the conditions for the survival of the fortifications. Due to a series of limitations that the rooms have, and due to the functional deficiencies, such buildings become troublesome and they lack appropriate care. Users treat them as temporary and are not aware of their great aesthetic and historical values.

Also very important are the historical-architectural elements, which have been preserved in the current form of the object. These include historical examples of wall ties, unique window and door joinery, preserved wooden gates, shooting ranges, windows and grilles in shooting ranges, former ventilation telescopes, structure and layout of the ramparts with heights, as well as the spouts located around the main Donjon Square.

\section{Characteristics of the current functioning of the Kłodzko Fortress}

Although the Kłodzko Fortress is an unique example of military architecture, its tourist potential is not fully exploited. This is due to the low degree of access to tourist purposes and the lack of financial resources allocated for its development. The object itself is very well preserved, however, its original form has not been fully preserved due to later reconstructions. Lack of use and exposure of the Fortress to weather conditions caused it to lose its aesthetic values.

Currently, there are no economic and industrial activities in the Fortress area. The remains of previous users are slowly being demolished and the area is being cleaned up and restored to its original state if possible. Thanks to these actions, it is possible to make the object available in the future on a much larger scale than before. At present, it is only $10 \%$ accessible for tourist purposes. ${ }^{11}$

The tourist route leading to the Main Fortress includes both underground mazes and a tour of the upper part. Over a kilometer of counter-mining sidewalks located under the battle slope of the Fortress are accessible from the several-kilometer-long underground route network. An additional attraction is the possibility to hear an artillery salute.

For the visitors there is also an offer enriched with a night tour of the Fortress. This is an unprecedented form of cognitive tourism, which enriched with acting performances of the Fortress employees, sound effects, and light illumination makes the tourist move into the atmosphere of old times. The facility also hosts various cultural and entertainment events. Night military maneuvers, demonstrations of historical drill, staging of the siege of the Fortress with the use of cannons, as well as fictional tours are the elements that appear on the annual Days of the Fortress. The cyclical ballistic reconstructions are also organized by the historical regiment group - the $47^{\text {th }}$ Prussian Infantry Regiment.

On the basis of data provided in 2017 by the Fortress Manager - Mr. Sławomir Małachowski, it can be concluded that the interest in the Kłodzko Fortress is constantly growing. In 2015 the facility was visited by about 130484 people, while in 2016 this number increased to 150650 people. In 2020 there are already about 200,000 tourists. This gives a good forecast for the development of the city of Kłodzko, because it shows that the interest of tourists in such facilities is growing.

In mid-2017, Kłodzko received funds for a project concerning the reconstruction of the historical path covering the spaces and facilities of the Kłodzko Fortress. The works started in 2018 with the cutting of invasive greenery on the eastern slopes of Forteczna Mountain. The didactic path starts from Czeska Street, in the reconstructed historical garden of the Commander, located in the outer part of the Fortress. It continues on the outside of the walls on the eastern slope and inside the military facility (Fig. 2). Along the route there are elements of small architecture, i.e., benches, lighting, information boards describing fragments of soldiers' lives in the Fortress. ${ }^{12}$ 


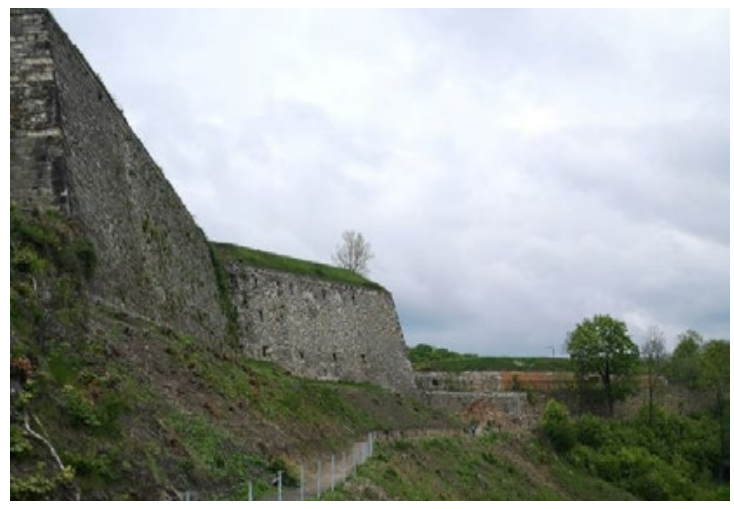

Fig. 2. The didactic path along the walls of the Fortress

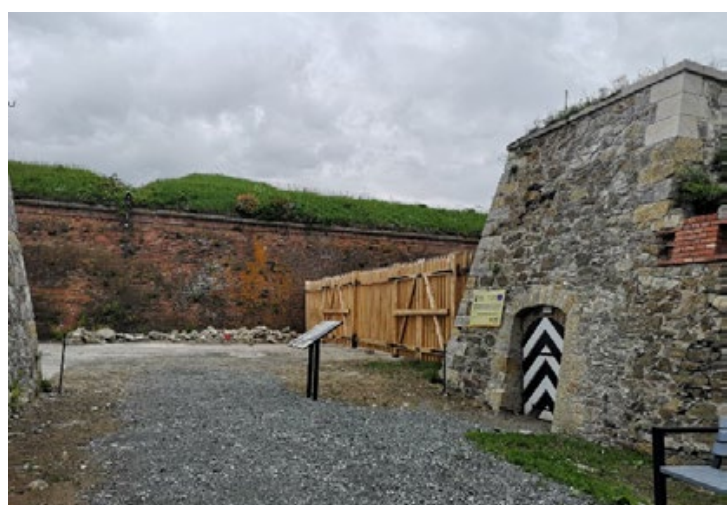

Fig. 3. View of renovated spaces on the Fortress

In connection with obtaining EU funds, several rooms of the Fortress were adapted for cultural, exhibition and educational purposes. The necessary facilities for the stage were also created. The cultural and exhibition offer was extended by innovative, multimedia solutions, i.e., mapping, presented in a renovated pen (Fig. 3). The walls, vaults and slope were renovated and secured along the whole path. ${ }^{13}$ Works aimed at clearing the ramparts of self-seeders and vegetation threatening the construction of the walls are also being gradually carried out.

\section{The Kłodzko Fortress - analysis and research}

The problem of looking for a way to use and develop the Fortress is extremely topical. Conclusions drawn from the research carried out on the object are the basis for carrying out conservation and adaptation works.

Since 2016, the Kłodzko Fortress has been hosting student internships under the supervision of academic staff of the Faculty of Civil Engineering and Architecture at the Lublin University of Technology. Until one year, during field trips, inventory works are carried out on the facility. The result of these works is the first in the history of the Kłodzko Fortress measurement-drawing inventory of the object.

At each of the stages, a number of tests were also carried out, which consisted of measurements of the moisture condition of the walls, their condition and a general assessment of the technical condition of the object. Samples of the walls were also taken, on the basis of which more detailed tests of moisture and salinity were later performed. Additionally, the photographic documentation and a 3D scan of the Fortress was created. ${ }^{14}$

The research papers prepared by students from the Lublin University of Technology became the subject of their master's theses on the field of civil engineering. They touched upon, among other things, the subject of adaptation of a fragment of casemates, analysis of layers and damage to the wall, projects of replacing the surface of the Donjon courtyard, repairing walls or improving the operation of the dike drainage system.

Based on the inventory of the object and the local vision, the diploma and master's theses in architecture were also created. Based on multi-faceted analyses, the students developed a functional-spatial plan for the Fortress. This made it possible to incorporate a number of many functions into such a complex historical complex as the Kłodzko Fortress.

In 2017, the Master thesis was completed entitled "Revitalization of the Kłodzko Fortress with an adaptation of the Donjon". The main goal of the project was to reconcile the preservation of the character of the object with the introduction of new functions. The design concept included both the adaptation of the existing rooms, as well as a proposal for new cubatures and the creation of recreational spaces within the fortress. The designed elements were developed in such a way that they clearly distinguish themselves both in material and form from the existing fortress walls (Fig. 4). 


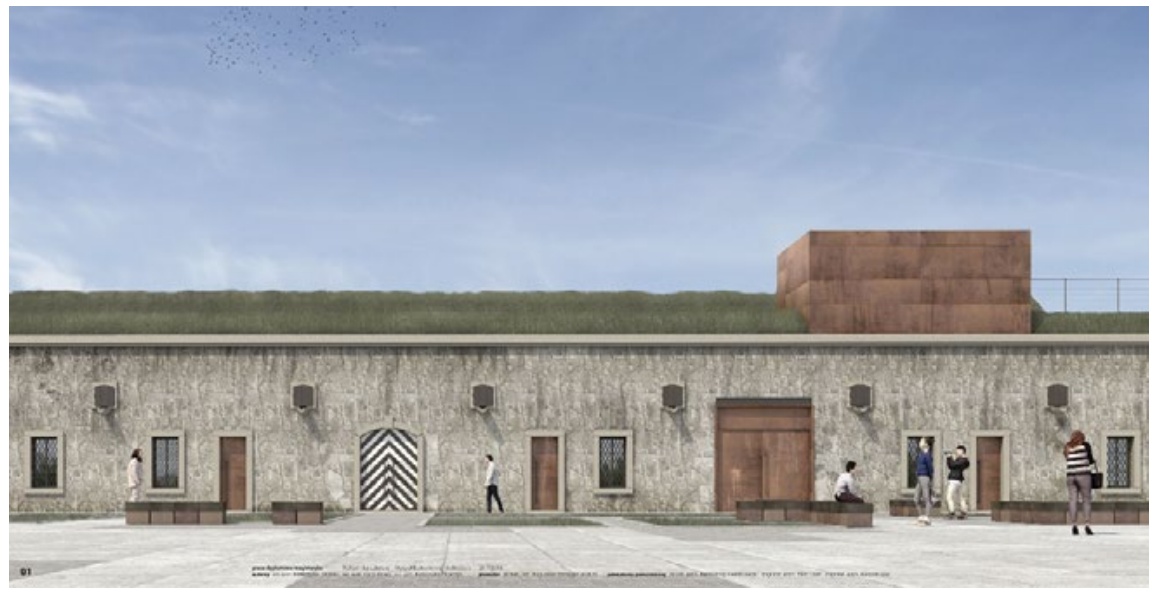

Fig. 4. Visualization of the Donjon elevation, proposal of introducing new elements, authors K. Drobek, K. Knap, K. Tkaczyk

The project was based on the idea of a tourist path, which would be led in such a way that almost the entire route the tourist, who becomes somehow a spectator, is stimulated at every step. Appropriate arrangement of various types of attractions would allow to experience the essence of the monument. It was also proposed to create public spaces, which would constitute areas adapted to the needs of tourists of different ages. Recreation zones complement the proposed functional plan of the Fortress and, similarly to the cubature objects, emphasize the value of the object, using the best features of the physiognomy of a military work. ${ }^{15}$

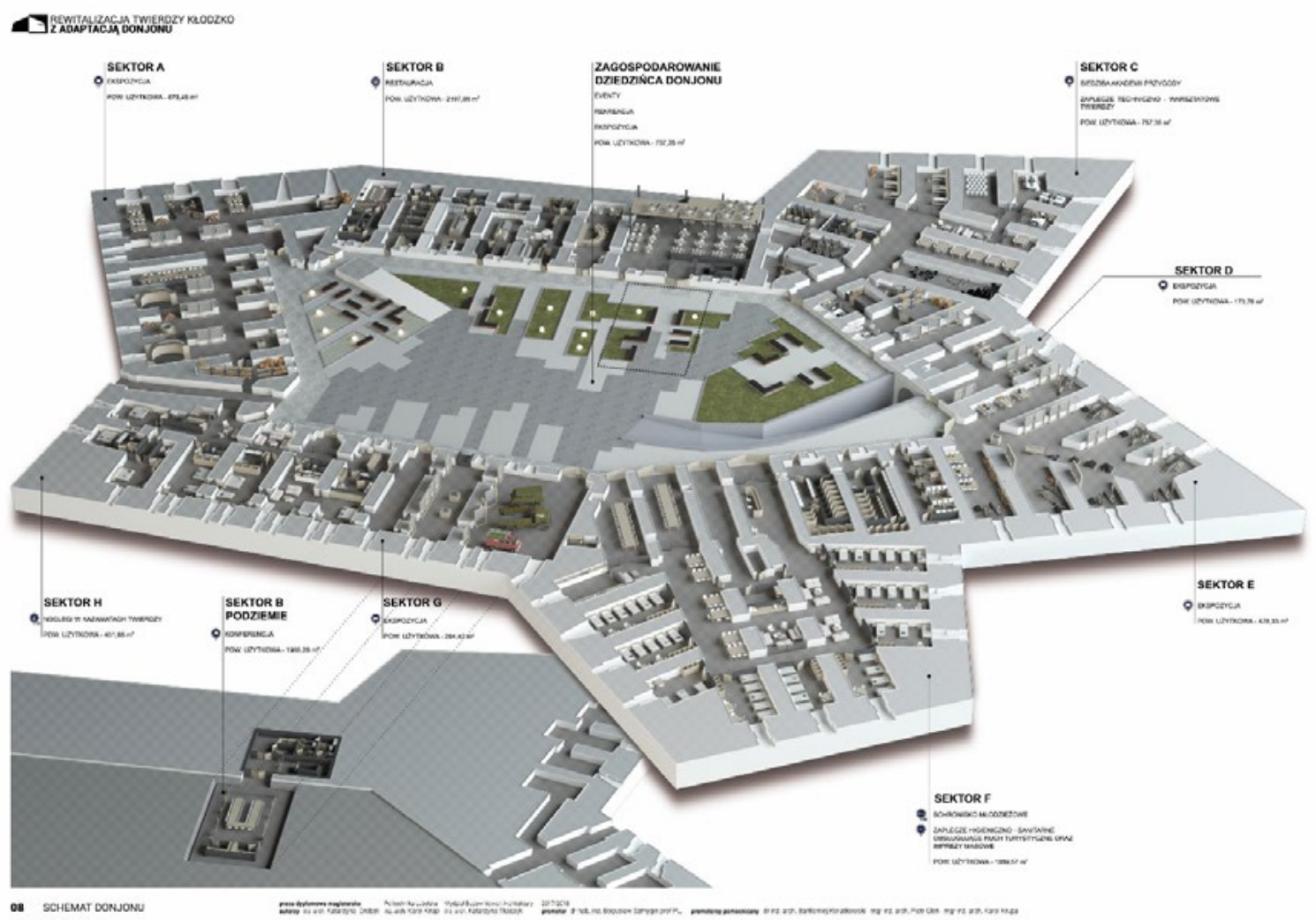

Fig. 5. The Donjon scheme - the adaptation proposal, authors K. Drobek, K. Knap, K. Tkaczyk

15 Drobek K, Knap K. Tkaczyk K, Rewitalizacja Twierdzy Kłodzko wraz z adaptacja Donjonu, praca dyplomowa magisterska obroniona na Wydziale Budownictwa i Architektury Politechniki Lubelskiej w 2017 roku, promotorzy: prof. dr hab. inż. Bogusław Szmygin, dr inż. arch. Bartłomiej Kwiatkowski. 
The focus was largely on the Donjon adaptation. It was divided into 8 sectors with different functions. Among other things, it was proposed to create a catering function in place of one of the halls, located in the western curtain, an exhibition function with different themes, an accommodation, a conference function, and a place for the headquarters of the Adventure Academy (Fig. 5).

The diploma project assumes that thanks to the changes proposed by the authors to the Kłodzko Fortress, the facility will cease to be a one-time visiting point and will become a place to which tourists, as well as Kłodzko residents themselves, will return.

In 2019, two more works related to the object, during which the students focused on two entrance zones for the Fortress, were completed at the Lublin University of Technology. The first project was made by Kostiantyn Pinkovskyi, entitled "Revitalization of the Kłodzko Fortress with adaptation of the entrance to the underground route" covered the area of the fortification from the side of the town. The new cubature was located in the place of the existing entrance to the Underground Tourist Route, which was incorporated into the designed object. The pavilion proposed to create an exposition related to the history of Lower Silesia and Kłodzko. There was also a café with a rest zone for tourists and an additional underground parking lot. The designed object fits in well with the terrain, thanks to dividing it into two separate blocks differentiated by levels (Fig. 6). ${ }^{16}$

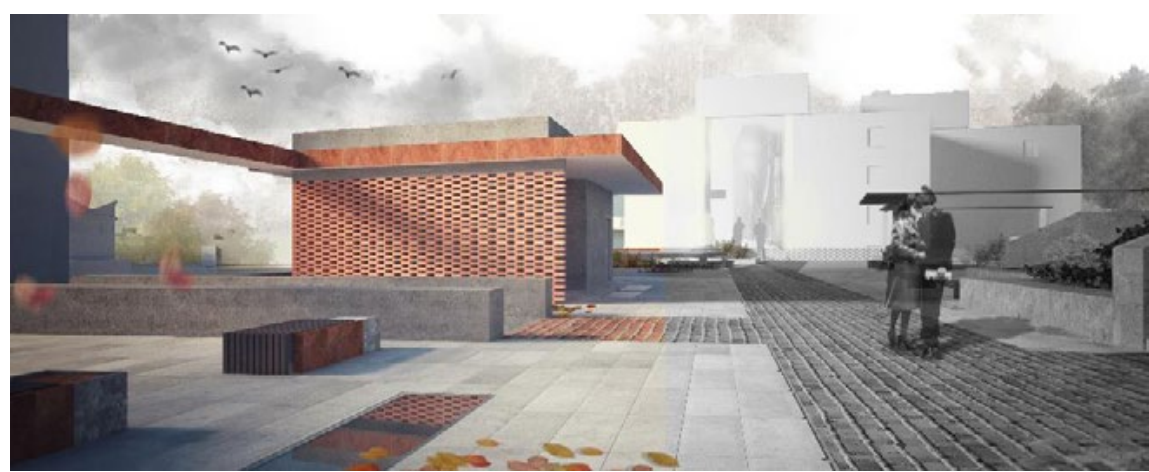

Fig. 6. Visualization of the new pavilion on the Czeska Street, author K. Pinkovskyi

The second work entitled "Adaptation of the entrance zone of the Kłodzko Fortress" done by Pavlo Lozovskyi was aimed at improving the northern part of the fortification to serve tourist traffic, i.e., creating a new entrance pavilion and increasing the number of parking spaces for coaches and cars. Additionally, the project of adaptation of the Field Ravelin for exhibition purposes was carried out. The materials used in the concept are consistent with other ideas for the use of the Fortress and perfectly match the historic character of the object (Fig. 7). ${ }^{17}$

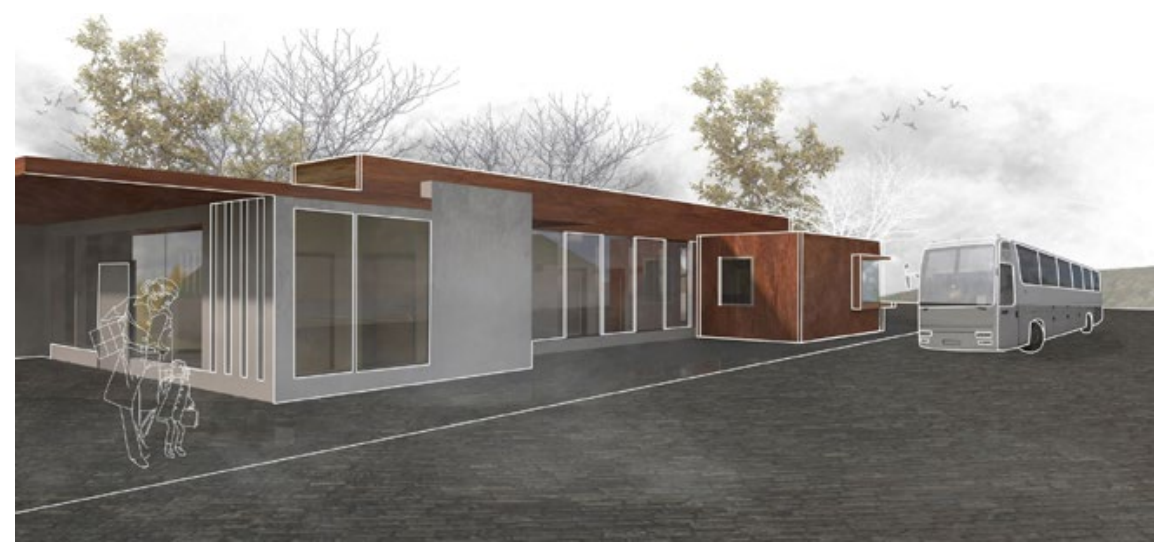

Fig. 7. Visualization of the new pavilion on the Czeska Street, author K. Pinkovskyi

16 Pinkovskyi K., Rewitalizacja Twierdzy Kłodzko z adaptacja wejścia do trasy podziemnej, praca dyplomowa inżynierska obroniona na Wydziale Budownictwa i Architektury Politechniki Lubelskiej w 2018 roku, promotor: dr inż. arch. Bartłomiej Kwiatkowski.

17 Lozovskyi P., Adaptacja strefy wjazdu Twierdzy Kłodzko, praca dyplomowa inżynierska obroniona na Wydziale Budownictwa i Architektury Politechniki Lubelskiej w 2018 roku, promotor: dr inż. arch. Bartłomiej Kwiatkowski. 


\section{Adaptation possibilities}

Adaptation of post-fortress facilities is extremely problematic. Due to huge costs, design restrictions and conservation restrictions, investors are effectively discouraged from trying to adapt fortifications and invest in them.

First of all, it should be remembered that any interference in the object is necessary to stop its destruction. The management of historical sites is a threat to the degradation of their cultural values, but it is also a chance for their survival. This is possible if the development is carried out in accordance with the conservation concept. The basic condition, which would result in effective protection of the monument, is its continuous use, because it forces current repairs and conservation. The commercial use, on the other hand, allows the objects to gain funds for its maintenance. ${ }^{18}$

It is worth remembering, however, that the adaptability of an object is strongly limited due to its structural and material features, resulting primarily from the specificity of its function. It is a characteristic feature of military works, where small rooms, scaled thicknesses of construction elements, limitation of the number and size of window openings strictly resulted from their original purpose. These are the essential properties that are a key obstacle in attempting to adapt the object for new functions, taking into account the applicable laws and technical standards.

The main goal of the changes carried out at the Kłodzko Fortress should be to increase tourist's awareness of the monument. It is important to carry out such activities, thanks to which the Kłodzko Fortress could be made available on a larger scale and perform better didactic functions. The building itself, with its architectural form and unusual character of the place, is able to attract many people not interested in the military on a daily basis. Thanks to the increased offer of services, the facility should start to generate more profits, which will contribute to its economic independence.

At the very beginning, one should consider increasing the didactic offer, understood in a slightly broader context than the museum functions themselves. Various active forms of knowledge transfer about historical, scientific and artistic values should be provided, which would provide access to the exhibition for a wide range of visitors. Various presentation techniques, such as all kinds of mock-ups, information boards, multimedia presentations, museum exhibitions or interactive forms of sightseeing would certainly improve the reception of the object. Introducing historical scenery into the open air would make the didactic path more attractive.

With the expansion of the didactic offer and the introduction of new services related to the tourism sector, it is appropriate to introduce the accommodation function also on the Kłodzko Fortress. The rapidly growing tourist sector increases the demand for new accommodation, so a good option is to use this type of facilities for hotel functions. The unique character of the fortress facilities is able to provide an unusual experience. ${ }^{19}$ And the casemate interiors on the first level of the Donjon, are a suitable place to adapt them for hotel purposes or for a youth hostel.

All of the above mentioned adaptation proposals are combined with the introduction of support functions. A catering, exhibition function and improved technical and communication infrastructure will make the facility not only an interesting option for tourists to visit, but also a place visited by Kłodzko residents.

The introduction of accommodation and organization of cultural events while locating the restaurant function would attract a much larger number of tourists who could stay in Kłodzko and the Fortress itself for more than one day.

\section{Conclusions}

Kłodzko is the most important town in the Kłodzko Valley, and a good starting point. Within a radius of $30 \mathrm{~km}$ from the town there are many health resorts, and the region itself abounds in various tourist attractions. In the area there is also a local trail of military objects - the "Giant Complex". Such a location and the surroundings of the cities increase its attractiveness and possibilities of attracting tourists to it. The moment of increasing

18 Molski P., Kozarski P., Zagospodarowanie i konserwacja zabytkowych budowli, Poradnik, Warszawa 2001 r., s. 7.

19 Cudny W., Rouba R., Hotelarstwo jako sposób na rewitalizację zabytkowych obiektów militarnych pochodzących z XIX i XX w., Ochrona Zabytków nr 3-4, 2012 r, s. 109. 
tourist availability and expanding the range of services offered at the Fortress, the rank of the city itself and the facility will increase. Therefore, it is necessary to carry out comprehensive adaptation and renovation works on the Kłodzko Fortress.

This building is a unique example of a military architecture, distinguished by unique historical and cultural values. It has an extraordinary potential, which is not utilized at the moment. The student projects presented in the paper are the basis for the future of the Kłodzko Fortress and its consideration on a global level, as one great assumption. On the object works are constantly carried out in order to increase its touristic accessibility. However, without creating a single plan containing a multi-faceted analysis of the Fortress development possibilities and design concept, this fortification will not work properly. The introduction of new functions would have a significant impact on its development. On the other hand, the continuous functioning of the Fortress complex would primarily contribute to stopping the degradation of the facility, but could also ensure further development in the future.

\section{Literature}

[1] Bogdanowski J., Architektura obronna w krajobrazie Polski. Od Biskupina do Westerplatte, Warszawa - Kraków 1996.

[2] Bogdanowski J, Sztuka obronna, Kraków 1993.

[3] Bukal G., Gerhard Cornelius Walrave i holendersko-pruska fortyfikacja na ziemiach polskich, Warszawa 1995.

[4] Broniewski T., Kłodzko, Śląsk w zabytkach sztuki, Wrocław 1963.

[5] Cudny W., Rouba R., Hotelarstwo jako sposób na rewitalizację zabytkowych obiektów militarnych pochodzących z XIX i XX w., Ochrona Zabytków nr 3-4, 2012, s. 107-122.

[6] Drobek K, Knap K. Tkaczyk K., Rewitalizacja Twierdzy Kłodzko wraz z adaptacja Donjonu, Politechnika Lubelska, 2017.

[7] Dziewulski W., Zarys rozwoju przestrzennego Kłodzka od czasów najdawniejszych do drugiej wojny światowej, T. III, Kłodzko 1959.

[8] Gleń P., Krupa K. The use of secondary build-up in historical fabric based on the donjon of Kłodzko Fortress, E3S Web of Conferences, 2018, vol. 49, s. 1-10.

[9] Guerquin B., Zamki Śląskie, Warszawa 1957.

[10] Lozovskyi P., Adaptacja strefy wjazdu Twierdzy Kłodzko, Politechnika Lubelska, 2019.

[11] Małachowicz E., Nowożytne fortyfikacje Śląska europejskim dziedzictwem kultury, Fortyfikacja tom XII, Warszawa 2002.

[12] Małachowicz M., Zabytki fortyfikacji nowszej, specyfika zasobu, a metody ochrony, Giżycko 1997.

[13] Małachowicz M., Zasoby fortyfikacji nowszej i problemy ich ochrony na obszarze Dolnego Śląska, Giżycko - Twierdza Boyen, 1997.

[14] Triller E., O Lisowczykach w Ziemi Kłodzkiej, Rocznik Ziemi Kłodzkiej 1958, T. III, Kłodzko 1959.

[15] Małachowicz M., Karnicki R., Podruczny G., Plan ochrony parku kulturowego dla Fortecznego Parku Kulturowego - Twierdza Kłodzko w Kłodzku, Wrocław - Kłodzko V, 2007.

[16] Molski P., Kozarski P., Zagospodarowanie i konserwacja zabytkowych budowli, Poradnik, Warszawa 2001.

[17] Pinkovskyi K., Rewitalizacja Twierdzy Kłodzko z adaptacją wejścia do trasy podziemnej, Politechnika Lubelska, 2019.

\section{Webpages}

[18] http://www.twierdzaklodzko.pl, data odczytu: 25.01.2018.

[19] http://www.kłodzko.pl, data odczytu: 2.03.2018.

[20] http://www.naszesudety.pl, data odczytu: 2.03.2018.

[21] http://www.dawnekłodzko.pl, data odczytu: 15.01.2018.

[22] http://www.zamkipolskie.pl, data odczytu: 24.01.2017. 